\title{
The antitumor effect of arsenic trioxide on hepatocellular carcinoma is enhanced by andrographolide
}

\author{
Xuhua Duan ${ }^{1, *}$, Tengfei Li $^{1, *}$, Xinwei Han ${ }^{1, *}$, Jianzhuang Ren ${ }^{1, \#}$, Pengfei Chen ${ }^{1}$, Hao \\ $\mathbf{L i}^{1}$ and Shaojun Gong ${ }^{1}$ \\ ${ }^{1}$ Department of Interventional Radiology, The First Affiliated Hospital, Zhengzhou University, Zhengzhou, Henan Province, \\ People's Republic of China \\ "These authors contributed equally to this work and share co-first authorship \\ \#These authors contributed equally to this work \\ Correspondence to: Xinwei Han, email: xinwei_han@126.com \\ Jianzhuang Ren, email: jianzhuang_ren@126.com
}

Keywords: andrographolide, $\mathrm{As}_{2} \mathrm{O}_{3}$, HepG2 cells, apoptosis, EphB4

Received: February 14, $2017 \quad$ Accepted: June 02, 2017

Published: June 27, 2017

Copyright: Duan et al. This is an open-access article distributed under the terms of the Creative Commons Attribution License 3.0 (CC BY 3.0 ), which permits unrestricted use, distribution, and reproduction in any medium, provided the original author and source are credited.

\section{ABSTRACT}

High concentrations of arsenic trioxide $\left(\mathrm{As}_{2} \mathrm{O}_{3}\right)$ are used to treat acute promyelocytic leukemia and solid tumors, with negative side effects to normal cells. Andrographolide is a traditional Chinese medicine that exerts anti-cancer, anti-inflammatory, anti-virus, and anti-diabetic effects. Here, we tested the effects of combined andrographolide with $\mathrm{As}_{2} \mathrm{O}_{3}$ against hepatocellular carcinoma (HCC). We found that by increasing apoptosis, andrographolide synergistically enhanced the anti-tumor effects of As203 in HepG2 cells in vitro and in vivo. Furthermore, results from our microarray assays and experiments with mouse xenografts showed that EphB4 was downregulated by the combination of $\mathrm{As}_{2} \mathrm{O}_{3}$ plus andrographolide. These findings suggest that the combination of andrographolide and $\mathrm{As}_{2} \mathrm{O}_{3}$ could yield therapeutic benefits in the treatment of $\mathrm{HCC}$.

\section{INTRODUCTION}

Hepatocellular carcinoma (HCC), the most common primary malignancy of the liver, causes one million deaths worldwide annually. Approximately $53 \%$ of HCCassociated deaths occur in China $[1,2]$, and the incidence rate has been increasing over the past two decades [3]. In spite of new developments in treatment and clinical prevention strategies, the 5-year survival of HCC patients remains dismally low [4]. The majority of the poor prognoses were associated with drug resistance, cancer recurrence, and metastasis following treatment. Therefore, further research investigating effective therapies for HCC might help prolong the 5-year survival rate.

Arsenic trioxide $\left(\mathrm{As}_{2} \mathrm{O}_{3}\right)$ has been used in China for more than 2400 years to treat diverse ailments including tuberculosis and gastric ulcers [5]. Recently, $\mathrm{As}_{2} \mathrm{O}_{3}$ has been used to treat cancer $[6,7]$. Studies have been focused on the effect of $\mathrm{As}_{2} \mathrm{O}_{3}$ on solid tumors, including osteosarcoma, gastric carcinoma, colorectal carcinoma, and hepatocellular carcinoma, among others [8-11]. However, the high concentrations of $\mathrm{As}_{2} \mathrm{O}_{3}$ required to be effective against solid tumors are toxic to normal cells [12]. Andrographolide, isolated from the traditional medicinal herb Andrographis paniculate Nees, exerts several pharmacological effects, such as anti-cancer, antiinflammatory, anti-virus, and ant-diabetic, among other [13-16]. Recent studies indicated that andrographolide could increase radio-sensitivity, and stimuli-responsive chemotherapy $[17,18]$. Therefore, here we propose that andrographolide in combination with $\mathrm{As}_{2} \mathrm{O}_{3}$ could be used as a potential therapeutic agent against HCC. Indeed, andrographolide might act synergistically with $\mathrm{As}_{2} \mathrm{O}_{3}$ to increase the latter's toxic effects on liver cancer cells at reduced $\mathrm{As}_{2} \mathrm{O}_{3}$ concentrations.

\section{RESULTS}

Andrographolide synergistically enhanced the anti-tumor effects of $\mathrm{As}_{2} \mathrm{O}_{3}$ in $\mathrm{HepG} 2$ cells

We used MTT assay to explore the cytotoxicity effect of $\mathrm{As}_{2} \mathrm{O}_{3}$ andrographolide in HepG2 cells. Treatment with $\mathrm{As}_{2} \mathrm{O}_{3}$ alone for $48 \mathrm{~h}$ resulted in a dose- 
dependent inhibition of HepG2 cell growth. Such effect was increased in the presence of $400 \mathrm{nM}$ andrographolide (Figure 1A). Meanwhile, the $\mathrm{IC}_{50}$ value of $\mathrm{As}_{2} \mathrm{O}_{3}$ combined with andrographolide was $2.88 \mu \mathrm{M}$, which was lower than the value for $\mathrm{As}_{2} \mathrm{O}_{3}$ treatment alone $(6.23 \mu \mathrm{M})$ (Table 2). We then evaluated the synergistic inhibitory effect of $\mathrm{As}_{2} \mathrm{O}_{3}$ and andrographolide on cell growth by using the combination index (CI) method [19]. The CI value for the combination treatment was 0.68 at $\mathrm{IC}_{50}$ of $\mathrm{As}_{2} \mathrm{O}_{3}$ (Table 1). In addition, treatment with andrographolide alone ranging from 0 to $1600 \mathrm{nM}$ for $48 \mathrm{~h}$ did not induce cell death (Figure 1B). The morphological changes of HepG2 cells were consistent with cell viability assays (Figure 1C). We used another hepatocellular carcinoma cell line, Huh7, to test the anti-tumor effect of the combination treatment. The results from experiments on Huh7 cells were consistent with those from experiments using HepG2 or SNU449 cells (Supplementary Figure 1A, 1B) These results indicated that andrographolide synergistically enhanced the anti-tumor effects of $\mathrm{As}_{2} \mathrm{O}_{3}$ in Hepatocellular Carcinoma.

\section{Andrographolide's synergistic enhancement of $\mathrm{As}_{2} \mathrm{O}_{3}$, anti-tumor effects was independent of autophagy}

We hypothesized that the combination of andrographolide plus $\mathrm{As}_{2} \mathrm{O}_{3}$ induces autophagy on HepG2 cells. To test this, we performed MDC staining, which can reveal autophagic vacuoles in flow cytometry experiments. MDC staining in the presence of andrographolide and/or $\mathrm{As}_{2} \mathrm{O}_{3}$ was negative compared with the positive control (Figure 2A). The conversion of LC3-I into LC3-II by cleavage and the expression of autophagy-related gene 5 (Atg 5) are hallmarks of autophagy activation. Therefore, we measured the levels of LC3-II and ATG-5 and found that andrographolide and/or $\mathrm{As}_{2} \mathrm{O}_{3}$ did not induce autophagy (Figure 2B).

\section{Andrographolide increased $\mathrm{As}_{2} \mathrm{O}_{3}$-induced apoptosis in HepG2 cells}

To investigate the mode of cell death induced by the combination treatment of andrographolide with $\mathrm{As}_{2} \mathrm{O}_{3}$, we labeled cells with Annexin V and PI using flow cytometry [20]. Compared with the $\mathrm{As}_{2} \mathrm{O}_{3}$ treatment group, the combination therapy had a higher apoptotic rate in HepG2 (Figure 2C, 2D). On the other hand, treatment with andrographolide alone did not induce apoptosis, in agreement with cell viability assays.

Caspases are a family of cysteinyl aspartate-specific proteases, which are involved in cell apoptosis, with caspase-3 acting as the executioner caspase [21]. Western blot analysis showed that the combination treatment of $\mathrm{As}_{2} \mathrm{O}_{3}$ plus andrographolide yielded higher levels of
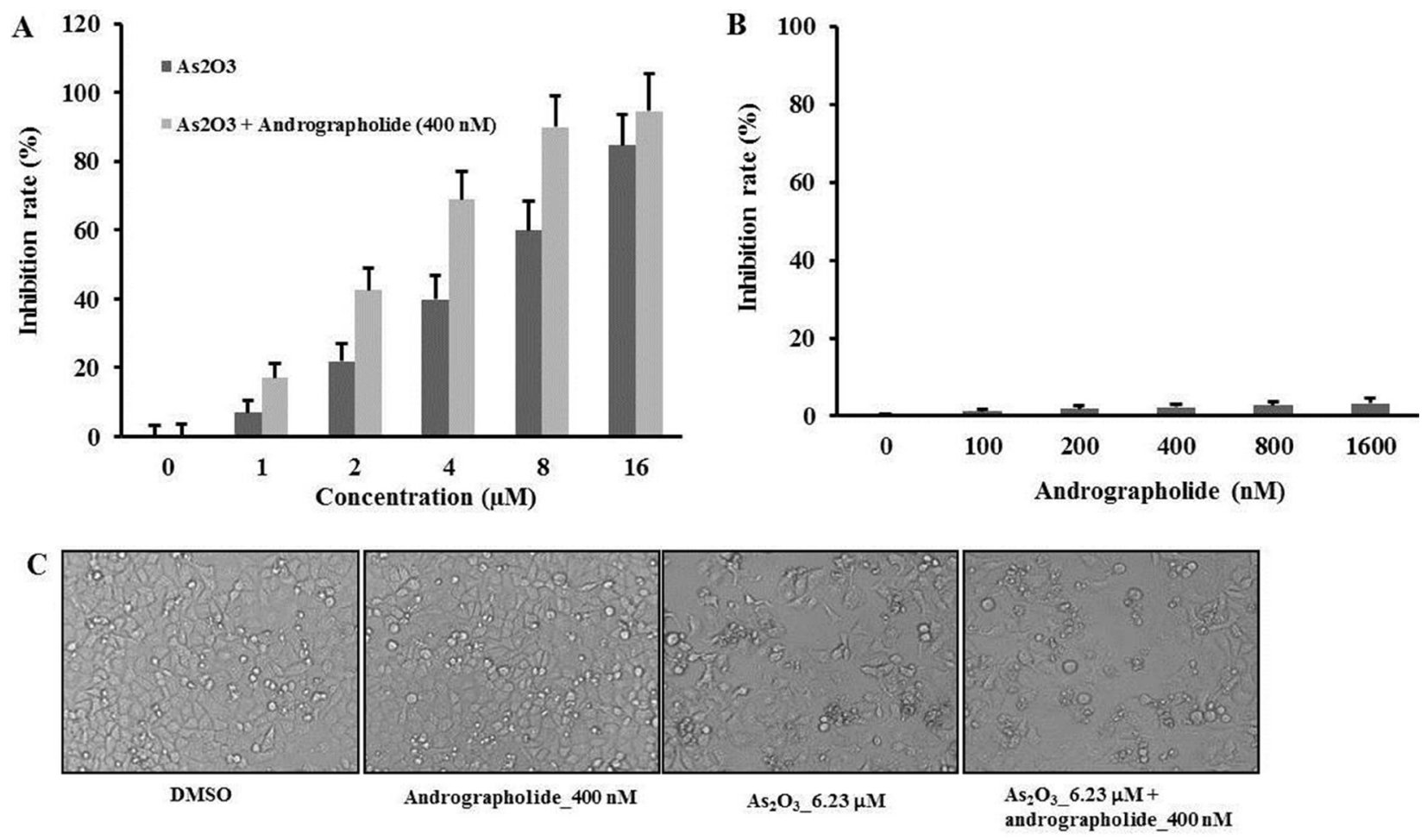

Figure 1: Andrographolide synergistically enhanced the anti-tumor effects of $\mathrm{As}_{\mathbf{2}} \mathrm{O}_{\mathbf{3}}$ on $\mathrm{HepG}_{2}$ cells. (A) HepG2 cells were treated with andrographolide from 100 to $1600 \mathrm{nM}$ for $48 \mathrm{~h}$. The growth inhibition rate was measured by MTT assay. (B) The cells were treated with $\mathrm{As}_{2} \mathrm{O}_{3}$ or $\mathrm{As}_{2} \mathrm{O}_{3}$ plus andrographolide at indicated time point. (C) The cells were treated with indicated treatment for $48 \mathrm{~h}$ and morphological changes were visualized using a light microscope at $200 \times$ magnification. Each experiment was repeated independently more than three times. 
Table 1: The IC50 and CI values of $\mathrm{As}_{2} \mathrm{O}_{3}$ alone treatment or the combination of $\mathrm{As}_{2} \mathrm{O}_{3}$ with andrographolide in HepG-2 cells

\begin{tabular}{|l|c|c|}
\hline \multicolumn{1}{c}{ Drugs } & IC50 values $(\boldsymbol{\mu M}, \mathbf{4 8} \mathbf{~ h})$ & CI values at IC50 \\
\hline $\mathrm{As}_{2} \mathrm{O}_{3}$ & 6.23 & - \\
\hline $\mathrm{As}_{2} \mathrm{O}_{3}+400 \mathrm{nM}$ AND & 2.88 & 0.68 \\
\hline
\end{tabular}

The concentration of $\mathrm{As}_{2} \mathrm{O}_{3}$ ranged from 0 to $16 \mu \mathrm{M}$.
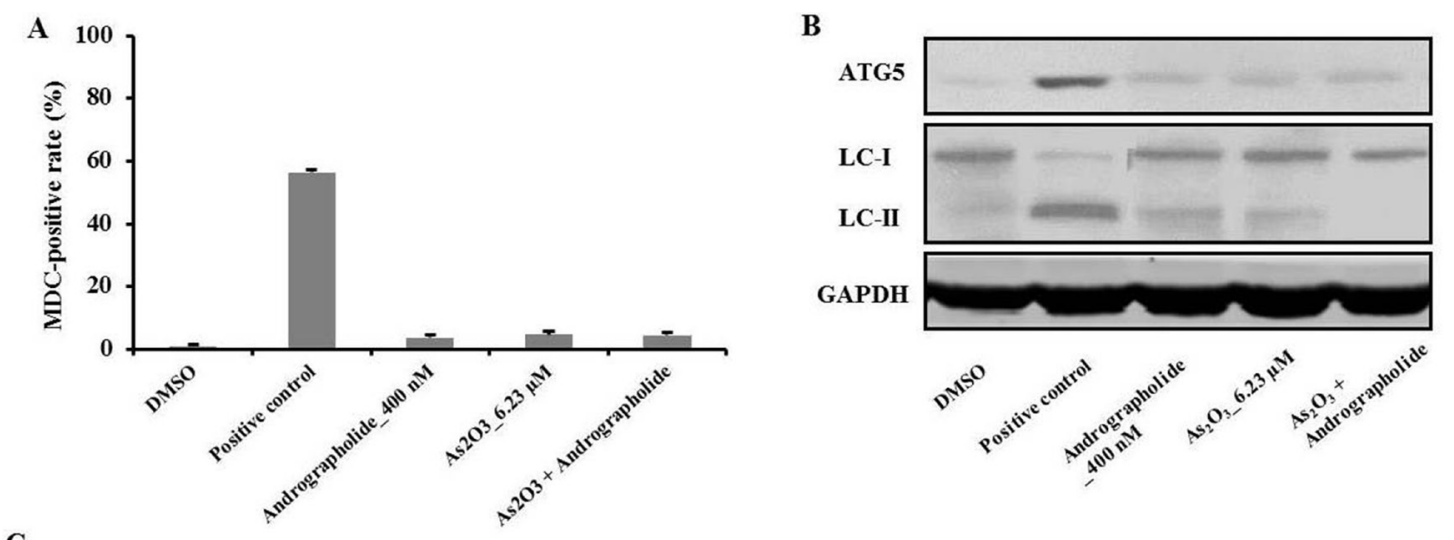

C
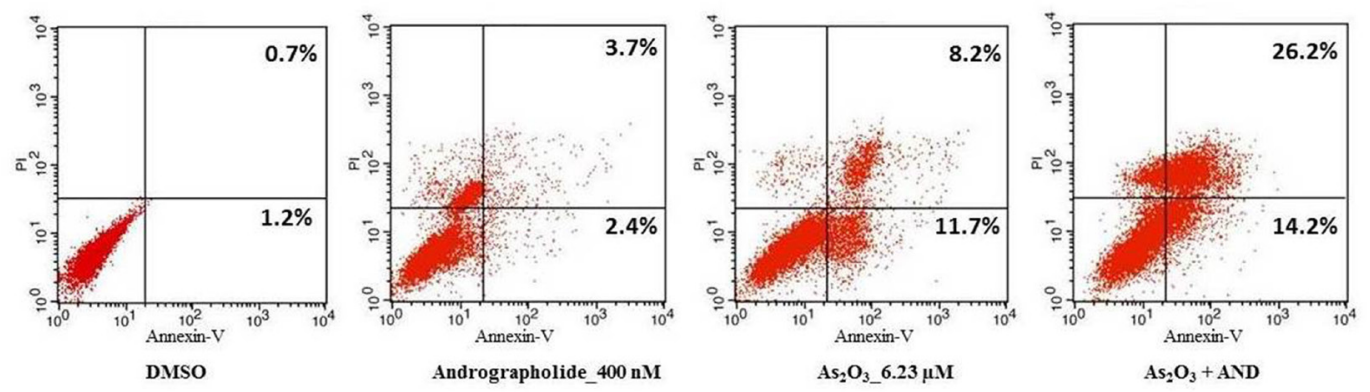

D
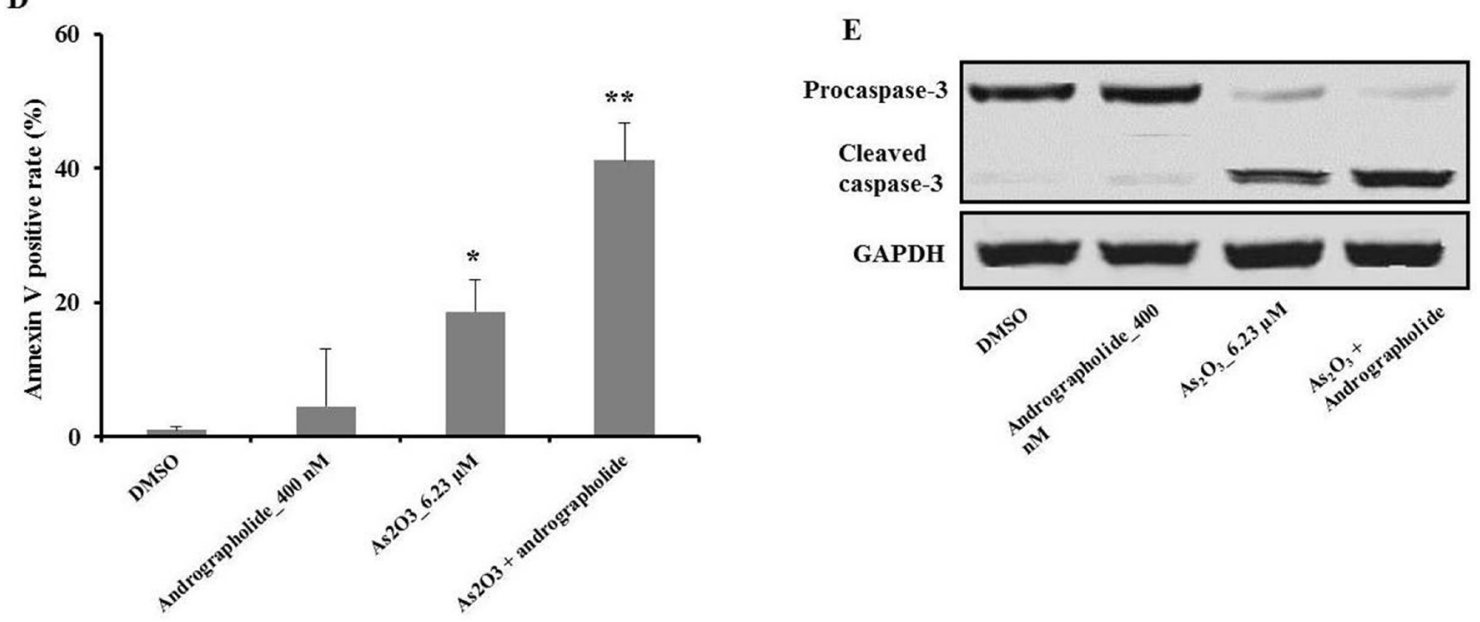

Figure 2: Andrographolide increased $\mathrm{As}_{2} \mathrm{O}_{3}$-induced apoptosis in $\mathrm{HepG2}$ cells, which was independent of autophagy. (A) HepG2 cells were treated with the indicated treatments for $48 \mathrm{~h}$, and then incubated with $\mathrm{MDC}$ at $0.05 \mathrm{mM}$ for $10 \mathrm{~min}$ at $37^{\circ} \mathrm{C}$. After washing twice with PBS, the cells were immediately analyzed by flow cytometry. (B) The levels of Atg-5 and LC-3 were analyzed using western blot. (C-D) The cells were treated with the indicated treatments and, after an additional incubation for $48 \mathrm{~h}$, the cells were stained with Annexin V and PI. Apoptotic cells were analyzed using flow cytometry. The fraction of viable cells: Annexin $\mathrm{V}^{-}, \mathrm{PI}^{-}$; lower left quadrant. Necrotic cells: Annexin $\mathrm{V}^{-}, \mathrm{PI}^{-}$; upper left; of early apoptotic cells: Annexin $\mathrm{V}^{-}, \mathrm{PI}^{-}$; lower right; of late apoptotic cells: Annexin $\mathrm{V}^{-}, \mathrm{PI}^{-}$. (E) The level of cleaved caspase-3 was analyzed by western blot. Each experiment was repeated independently more than three times. $* P<0.05, * * P<0.01$ by two-tailed $t$-test. 
cleaved caspase- 3 compared with $\mathrm{As}_{2} \mathrm{O}_{3}$ treatment alone. On the other hand, andrographolide alone did not affect the level of cleaved caspase-3 (Figure 2E). Taken together, these results indicated that andrographolide synergistically increased $\mathrm{As}_{2} \mathrm{O}_{3}$-induced apoptosis in HepG2 cells in a caspase-dependent manner.

\section{Andrographolide synergistically enhanced the anti-proliferative effect of $\mathrm{As}_{2} \mathrm{O}_{3}$ in $\mathrm{HepG} 2$ cells and downregulated EphB4}

We performed microarray analysis to identify differences in the expression of 37 genes under various treatments (Figure 3A). Among the examined genes, Ras, $V E G F R$, and EphB4 showed differential expression (Figure 3A). RT-PCR analysis confirmed that the expression of EphB4 was decreased in the presence of andrographolide plus $\mathrm{As}_{2} \mathrm{O}_{3}$ in HepG2 cells (Figure 3B). On the other hand, the levels of oncogenes Ras and VEGFR1 were unchanged. In addition, we also used western blot to measure the levels of EphB4 and VEGFR1 in HepG2 cells under the indicated treatments. The results showed that the level of EphB4 was decreased under the combination treatment, indicating that EphB4 was affected by the synergy between andrographolide and $\mathrm{As}_{2} \mathrm{O}_{3}$ (Figure 3C).

\section{Andrographolide enhanced the anti-tumor effect of $\mathrm{As}_{2} \mathrm{O}_{3}$ in $\mathrm{HepG} 2$ xenografts and the combination treatment inhibited the EphB4 pathway in vivo}

We next tested the effect of the combination treatment in vivo using HepG2 xenografts, choosing doses of andrographolide as previously described [13].
A

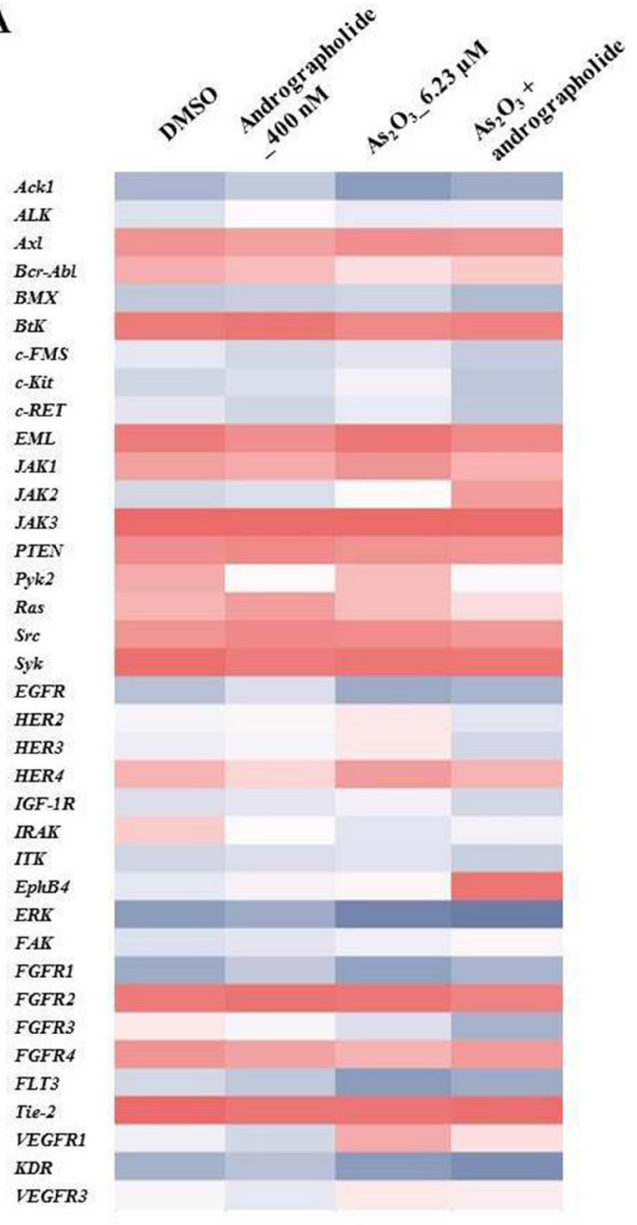

B

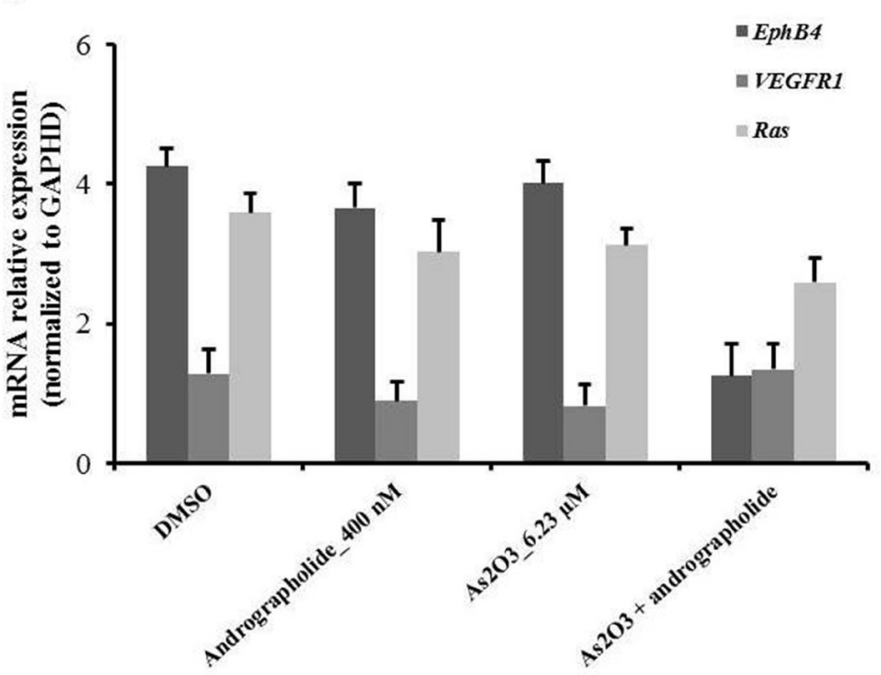

C

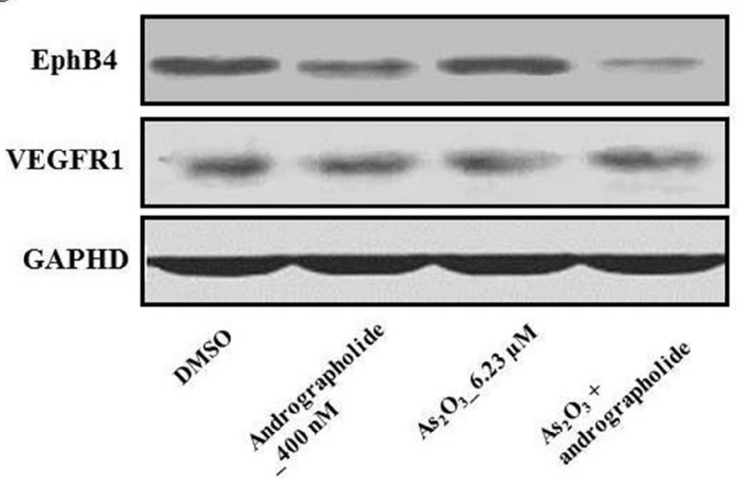

Small

Large

Figure 3: Andrographolide synergistically enhanced the anti-proliferative effects of $\mathrm{As}_{2} \mathrm{O}_{3}$ on $\mathrm{HepG}_{2}$ cells via downregulation of EphB4. (A) Heat map showing the effect of andrographolide plus $\mathrm{As}_{2} \mathrm{O}_{3}$ on the expression of HepG2 genes involved in andrographolide's synergistic anti-cancer activity. (B) Quantitative RT-PCR was used to evaluate the levels of EphB4, Ras and VEGFR1 in HepG2 cells. (C) The expression of EphB4 and VEGFR1 were analyzed by western blot. Each experiment was repeated independently more than three times. 
We also performed a pilot study to determine adequate doses for the combination treatment (Supplementary Figure 2). Tumor growth was inhibited after i.p. injection of andrographolide plus $\mathrm{As}_{2} \mathrm{O}_{3}$ for five weeks, compared with andrographolide or $\mathrm{As}_{2} \mathrm{O}_{3}$ monotherapy (Figure 4A). $\mathrm{As}_{2} \mathrm{O}_{3}$ monotherapy also inhibited the growth of tumors at a dose of $5 \mathrm{mg} / \mathrm{kg}$. At the end of the study, the mice were sacrificed, and the tumors were weighed. The combination treatment dramatically decreased tumor weights comparing with the other treatments (Figure 4C, 4D). In conclusion, andrographolide enhanced the antitumor effect of $\mathrm{As}_{2} \mathrm{O}_{3}$ in HepG2 xenografts.

Next, we found that the expression of EphB4 in tumor tissues was also decreased in the combination treatment group compared with the other treatment groups (Figure 5A, 5B). These results were consistent with in vitro data from western blot and RT-PCR experiments. Moreover, immunohistochemical analysis of tumors confirmed that EphB4 levels were decreased in the combination treatment group compared to the other treatment groups (Figure 5C). These results indicated that EphB4 downregulation correlated with the inhibitory effect of the combination treatment in HepG2 cells in vivo.

\section{Andrographolide increased $\mathrm{As}_{2} \mathrm{O}_{3}$-induced apoptosis in vivo}

We used TUNEL assay to measure the apoptotic effect of the combination treatment in vivo. Our results showed that the combination treatment induced a higher apoptosis rate in vivo compared with andrographolide or $\mathrm{As}_{2} \mathrm{O}_{3}$ alone. Indeed, andrographolide alone did not induce apoptosis at all (Figure 6A, 6B). These data showed that andrographolide increased $\mathrm{As}_{2} \mathrm{O}_{3}$-induced apoptosis in vivo. These results were consistent with our in vitro experiments.

\section{DISCUSSION}

Hepatocellular carcinoma is the leading cause of death in Asia, the second cause of cancer death in China, and its incidence is increasing in western countries $[1,22]$.
A

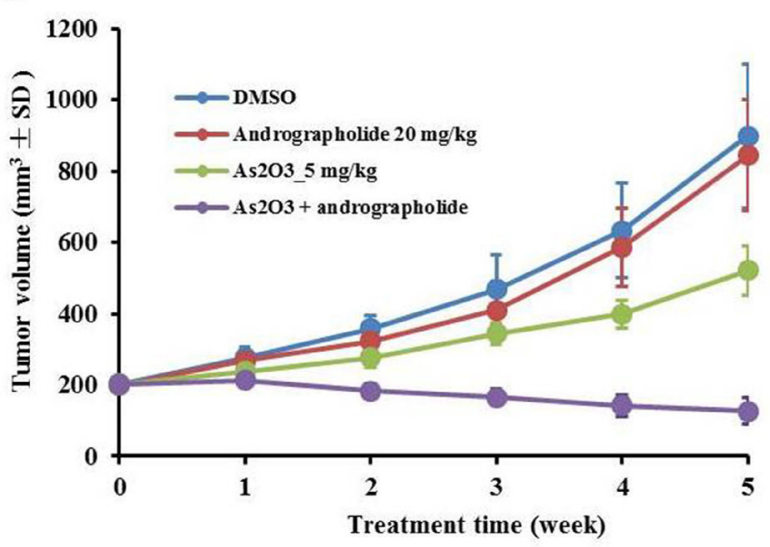

C

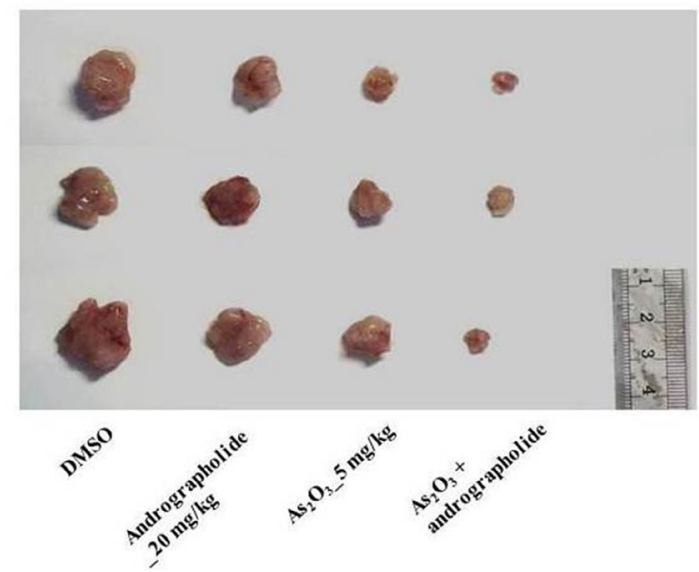

B

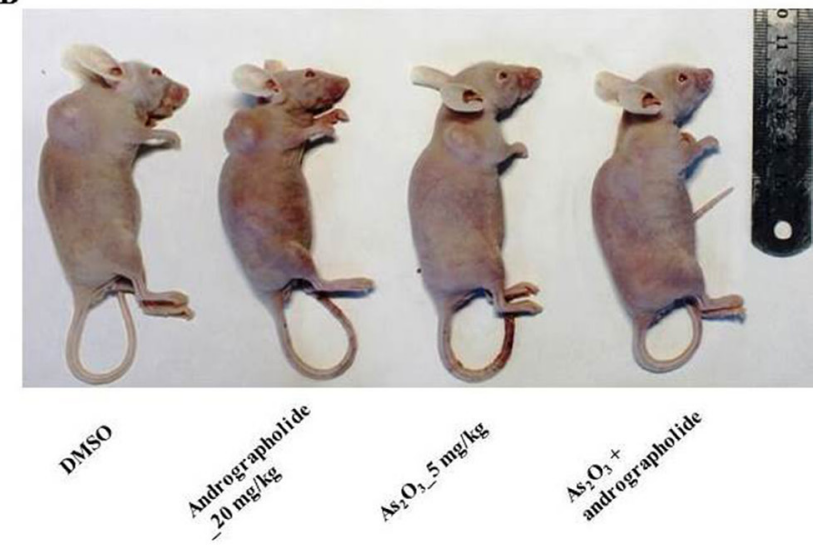

D

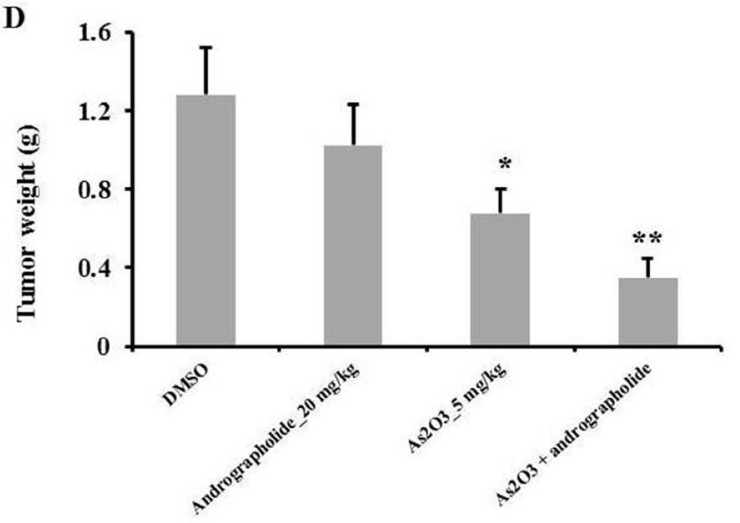

Figure 4: Andrographolide synergy enhanced the anti-tumor effect of $\mathrm{As}_{2} \mathrm{O}_{3}$ in vivo. (A) Tumor volumes of HepG2 xenografts were monitored weekly in each group. (B) Tumor bearing mice were sacrificed 5 weeks after treatment. (C) Tumors were resected from nude mice and weighted 5 weeks after treatment. (D) Graphs showing the average weights of harvested xenograft tumors $(n=6) . * P<0.05$, ** $P<0.01$ by two-tailed $t$-test. 
$\mathrm{As}_{2} \mathrm{O}_{3}$ is one of the major cytotoxic agents to treat acute promyelocytic leukemia (APL) and other leukemic cancer cells [5]. At therapeutic doses, $\mathrm{As}_{2} \mathrm{O}_{3}$ causes adverse side effects such as sever bone marrow depression, secondary malignancies, and cellular toxicity $[23,24]$. Indeed, $\mathrm{As}_{2} \mathrm{O}_{3}$ can exert anti-tumor effects on solid tumor cells such as HepG2 cells, but the effective concentration needs to be higher than $10 \mu \mathrm{M}$ [25]. HepG2 cells are more resistant to $\mathrm{As}_{2} \mathrm{O}_{3}$ than APL cells (effective dosage $<10 \mu \mathrm{M}$ ); therefore, drug resistance and chemotoxicity limit the therapeutic efficacy of $\mathrm{As}_{2} \mathrm{O}_{3}$ in treating solid HepG2 tumors [26-28]. In the present study, we discovered that andrographolide synergized with $\mathrm{As}_{2} \mathrm{O}_{3}$ to increase the latter's toxicity, leading to increased apoptosis in HepG2 cells in vitro and in vivo. Andrographolide was also able to enhance $\mathrm{As}_{2} \mathrm{O}_{3}$-mediated cell growth inhibition. The results were supported by the activation of cleaved caspase-3. Furthermore, we uncovered the underlying mechanism of apoptotic potentiation, which involves EphB4 downregulation upon treatment andrographolide plus $\mathrm{As}_{2} \mathrm{O}_{3}$ treatment.

$\mathrm{As}_{2} \mathrm{O}_{3}$ induces apoptosis in $\mathrm{HCC}[29,30]$ and andrographolide acts in synergy with $\mathrm{As}_{2} \mathrm{O}_{3}$ to induce cell death by abrogation of $\mathrm{As}_{2} \mathrm{O}_{3}$-induced $\mathrm{G} 2 / \mathrm{M}$ arrest [28]. In the present study, by activating cleaved caspase-3, andrographolide promoted $\mathrm{As}_{2} \mathrm{O}_{3}$ 's induction of apoptosis. Furthermore, our MDC staining experiments indicated that autophagy was not elicited by the combination treatment in HepG2 cells. In agreement with this, gene expression tests for LC3 and Atg-5 were negative. Additionally, results from in vivo experiments on xenografts further substantiated our findings. Our results demonstrated that andrographolide enhanced the anti-tumor effects of of $\mathrm{As}_{2} \mathrm{O}_{3}$ in $\mathrm{HepG} 2$ cells.

EphB4 is a member of the receptor tyrosine kinase (RTK) family, which promotes tumor tissue development, oncogenesis and progression [31-33]. We used microarray assays to study the mechanism underlying the synergism between $\mathrm{As}_{2} \mathrm{O}_{3}$ and andrographolide in HCC. Our data revealed that the expression of EphB4 in the combination treatment group was much lower than that in the groups treated with $\mathrm{As}_{2} \mathrm{O}_{3}$ or andrographolide alone in vitro. Results from RT-PCR and western blot experiments in vitro and in vivo were consistent with this finding. Additionally, our immunological assays also indicated that EphB4 was downregulated by the combination treatment. However, conflicting results have been reported for EphB4 in different tumor cells. A previous study reported that EphB4 is an important indicator of poorly differentiated hepatocarcinoma, with EphB4 expression correlating with
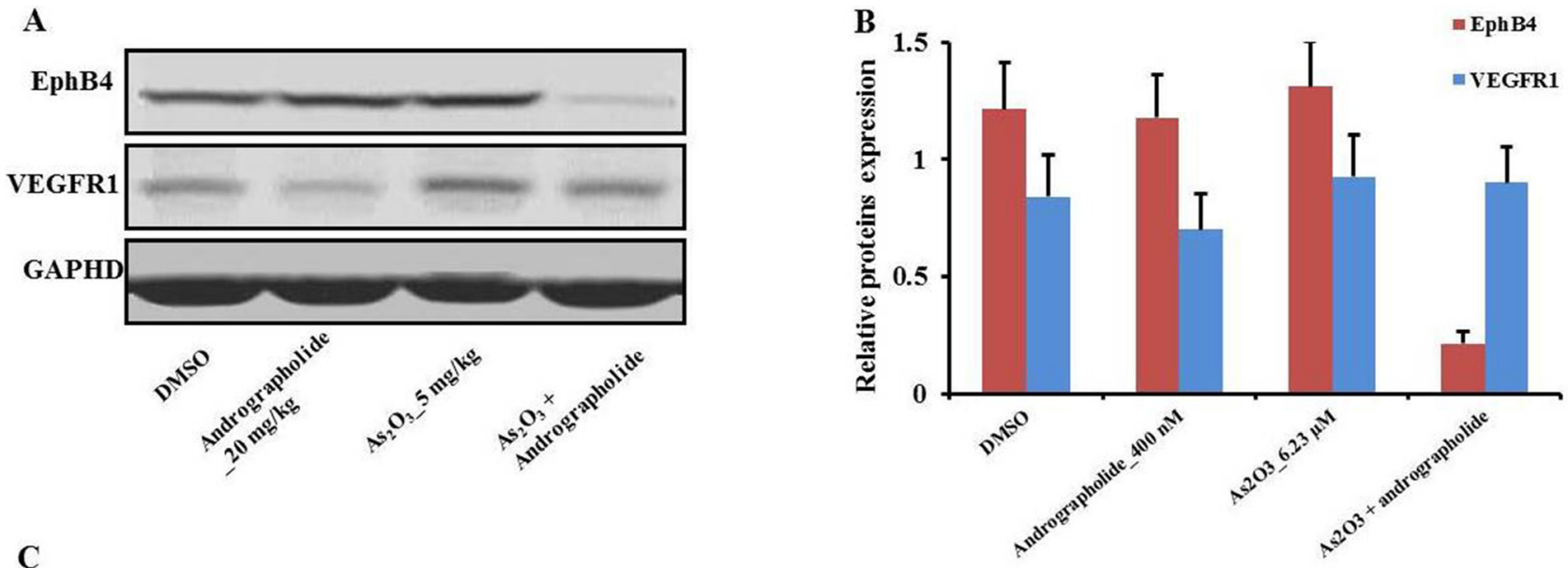

C

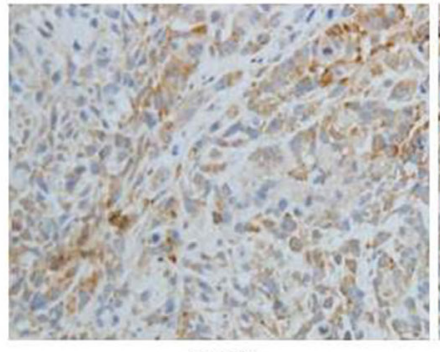

DMSO

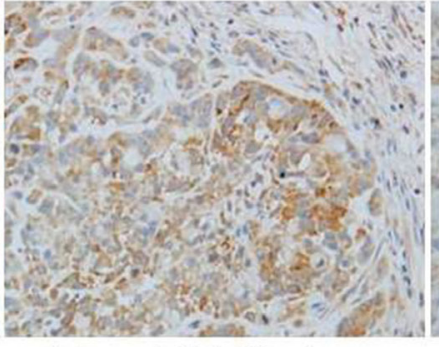

Andrographolide_20 mg/kg

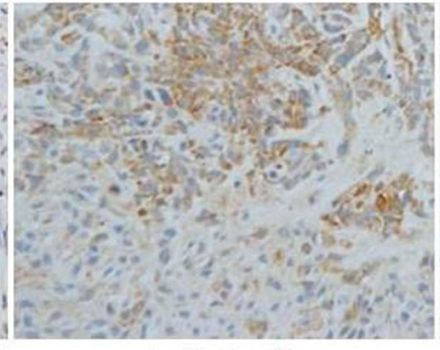

$\mathrm{As}_{2} \mathrm{O}_{3}{ }_{-} \mathrm{mg} / \mathrm{kg}$

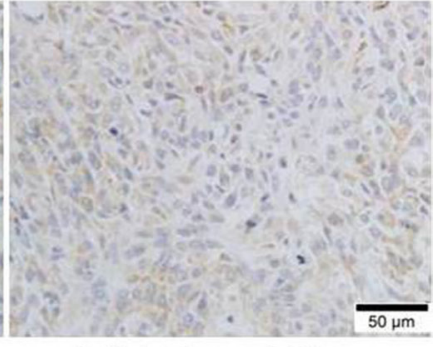

$\mathrm{As}_{2} \mathrm{O}_{3}+$ andrographolide

Figure 5: EphB4 downregulation enhanced andrographolide's promotion of $\mathrm{As}_{2} \mathrm{O}_{3}$ anti-tumor effects in vivo. (A) The levels of EphB4 and VEGFR1 were analyzed by western blot assay. (B) Quantitative results by western blot. (C) Immunohistochemical validation of EphB4 in representative HCC and control tissue sections stained with anti-EphB4 antibody. Each experiment was independently repeated more than three times. 
angiogenesis and tumor progression [34]. Furthermore, overexpression of EphB4 has been found in several tumor types including ovarian and prostate cancer, among others [35]. Lastly, in our experimental systems the expression of oncogenes Ras and VEGFR1 was unchanged. Therefore, further research is needed to uncover the mechanisms underlying EphB4 downregulation and its involvement in HCC tumor cell apoptosis.

In summary, we demonstrated that the andrographolide synergistically enhances $\mathrm{As}_{2} \mathrm{O}_{3}$ 's antitumor activity in HCC cells in vitro and in vivo. Specifically, andrographolide enhanced $\mathrm{As}_{2} \mathrm{O}_{3}$-induced apoptosis in a caspase-3 dependent manner via downregulation of EphB4. Thus, our data suggest that lower doses of $\mathrm{As}_{2} \mathrm{O}_{3}$ in combination with andrographolide could be used as chemotherapy for $\mathrm{HCC}$ with the potential to minimize the toxic side effects from $\mathrm{As}_{2} \mathrm{O}_{3}$ treatment alone.

\section{MATERIALS AND METHODS}

\section{Reagents}

Andrographolide (purity $>98 \%$ ) was purchased from the National Institutes for Food and Drug Control,
China. Arsenic trioxide $\left(\mathrm{As}_{2} \mathrm{O}_{3}\right)$, trypsin, phosphate buffer saline (PBS), ethylene diamine tetraacetic acid (EDTA), 3-(4,5-dimethyl-2-thiazolyl)-2,5-diphenyl-2-H-tetrazolium bromide (MTT), monodansylcadaverine (MDC), propidium iodide (PI), Annexin V, and rapamycin were purchased from Sigma Chemical Corp. (St. Louis, MO, USA). Primary antibodies against caspase-3, LC3, Atg-5, EphB4 and VEGFR1 were purchased from Santa Cruz Biotechnology (Santa Cruz, CA, USA). All the other chemical reagents in the study were of analytical reagent grade.

\section{Cell culture}

The human hepatoma cell lines HepG2, Huh7 and SNU-449 were obtained from the American Type Culture Collection (ATCC, Manassas, VA, USA) in 2016. The cells were cultured in RPMI1640 supplemented with 100 $\mu \mathrm{g} / \mathrm{mL}$ streptomycin, $100 / \mathrm{mL}$ penicillin and $10 \%$ fetal bovine serum at the atmosphere of $37^{\circ} \mathrm{C}$ with $5 \% \mathrm{CO}_{2}$.

\section{Cell viability assay}

HepG2, Huh7 or SNU-449 cells were seeded into 96-well plates (Corning, NY, USA) at a density of 1

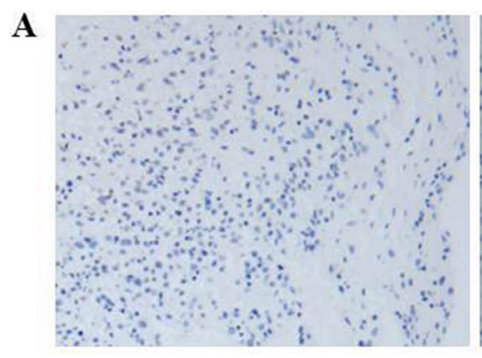

DMSO

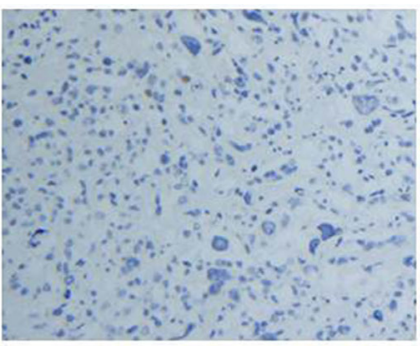

Andrographolide_20 mg/kg

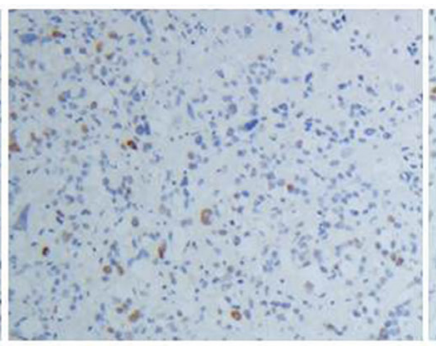

$\mathrm{As}_{2} \mathrm{O}_{3} 5 \mathrm{mg} / \mathrm{kg}$

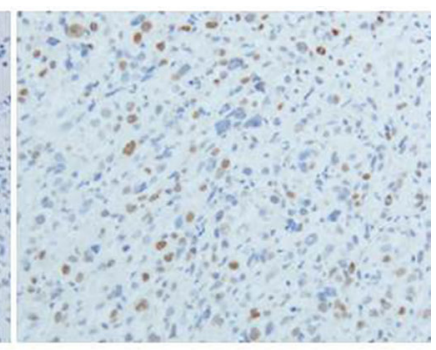

$\mathrm{As}_{2} \mathrm{O}_{3}+$ andrographolide

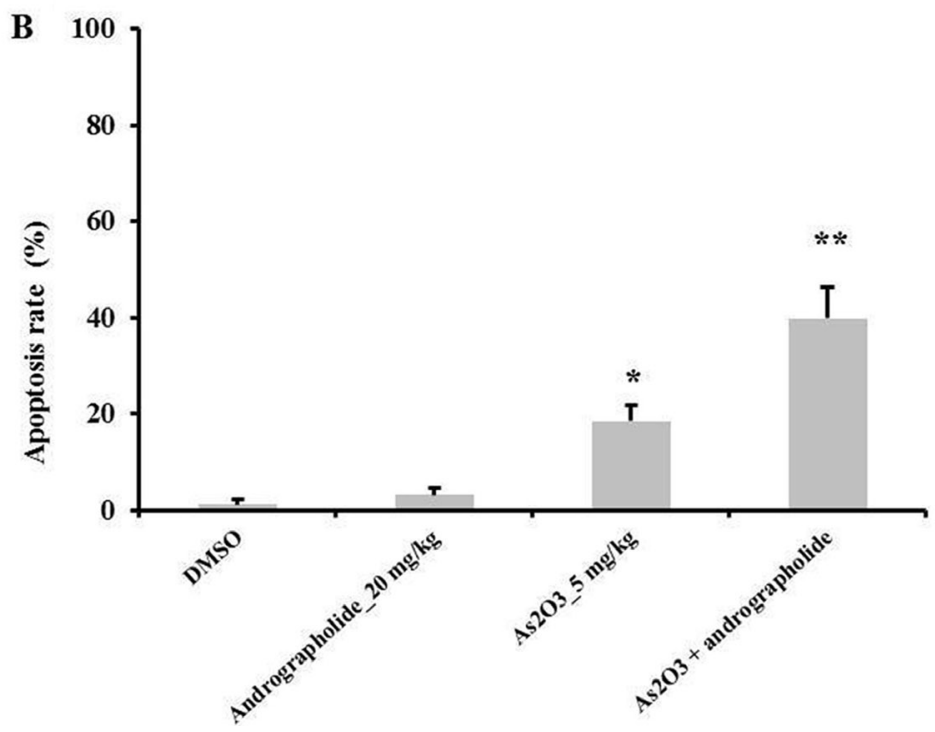

Figure 6: Andrographolide enhanced $\mathrm{As}_{2} \mathrm{O}_{3}$-induce apoptosis in vivo. (A-B) TUNEL assay was performed to determine the level of apoptosis in HepG2 tumor tissues $(n=3) . * P<0.05$, ${ }^{* *} P<0.01$ by two-tailed $t$-test. 
$\times 10^{4}$ cells/well. The culture medium was replaced with fresh medium after $48 \mathrm{~h}$ incubation and the cells were subjected to appropriate treatments. Then the cell viability was measured by MTT assay. Cells were cultured with $5 \mathrm{mg} / \mathrm{mL}$ MTT solution for $3 \mathrm{~h}$ at $37^{\circ} \mathrm{C}$. Then the culture medium was discarded and formazan produced was dissolved in dimethyl sulfoxide (DMSO) by shaking for $15 \mathrm{~min}$. Absorbance at $492 \mathrm{~nm}$ was measured with a microplate reader (Thermo Fisher Scientific). Cell inhibitory ratio was calculated as follow formula:

Cell growth inhibitory ratio $(\%)=$

$$
100 \times\left(\mathrm{A}_{490, \text { control }}-\mathrm{A}_{490, \text { sample }}\right) /\left(\mathrm{A}_{490, \text { control }}-\mathrm{A}_{490, \text { blank }}\right)
$$

\section{Observation of cell morphological changes}

HepG2 cells were seeded into 6-well plates at a density of $3 \times 10^{5}$ cell/well (Corning, NY, USA). Then, the cells were treated with indicated concentrations of andrographolide or/and $\mathrm{As}_{2} \mathrm{O}_{3}$ for $48 \mathrm{~h}$. The cellular morphologies were observed and captured by phase contrast microscope (Olympus America Inc., Center Valley, USA).

\section{Analysis of drug synergism}

Synergism analysis was performed following the method described previously [36]. Data from cell viability assay were employed to perform this statistical analysis. The combination-index (CI) was used to evaluate the influence of each of the two drugs independently, as well as both drugs simultaneously, calculated as follows:

$$
\text { Combination Index }(\mathrm{CI})=\mathrm{D}_{1} /(\mathrm{DX})_{1}+\mathrm{D}_{2} /(\mathrm{DX})_{2}
$$

D1 and D2 represent the concentration of combination treatment of drug 1 and drug 2 achieving $\mathrm{x} \%$ of the total drug effect, whereas $\left(D_{X}\right)_{1}$ and $\left(D_{X}\right)_{2}$ are the concentrations of drug 1 or drug 2, respectively, to achieve the same efficacy. The combination was synergistic when $\mathrm{CI}<1$, and antagonistic when $\mathrm{CI}>1$, and additive when $\mathrm{CI}=1$.

\section{Cell apoptosis assays}

PI, plasma membrane-impermeant fluorochrome, was used as an exclusion dye. Annexin $\mathrm{V}$ was used to detect phosphatidylserine (PS) exposure on the outer leaf of the plasma membrane. Apoptosis was quantitatively investigated by analysis of PI and Annexin V labelling using flow cytometry as previously reported [37]. Briefly, cells were collected after different treatments and incubation at $37^{\circ} \mathrm{C}$ for $48 \mathrm{~h}$, washed with cold PBS twice and centrifuged at $1200 \mathrm{rpm}$ for $5 \mathrm{~min}$. Then, the cells were suspended with mixed buffer supplemented with 5 $\mu \mathrm{L}$ Annexin V and $5 \mu \mathrm{L}$ and PI (Pierce Biotechnology, Rockford, IL, USA). After incubation at $4^{\circ} \mathrm{C}$ for $30 \mathrm{~min}$ in the dark, the cells were analyzed by flow cytometry.

\section{MDC staining assay}

MDC is an effective fluorescent dye used to detect autophagic vacuoles, which are part of autophagosomes [38]. HepG2 cells were seeded into 6-well plates and treated with AND or/and $\mathrm{As}_{2} \mathrm{O}_{3}$ treatments, and $100 \mathrm{nM}$ rapamycin was used as a positive control. After $48 \mathrm{~h}$ incubation, the cells were trypsinized, resuspended in DMEM medium, and centrifuged at $400 \times g$ for $10 \mathrm{~min}$. Then, the cells were washed with $1 \times$ cold PBS twice and resuspended, added into MDC solution $(20 \times)$, and incubated at $37^{\circ} \mathrm{C}$ for $40 \mathrm{~min}$. The autophagosomes were analyzed by a flow cytometry (BD Biosciences, Franklin Lake, NJ, USA). Rapamycin (200 nM) was used as a positive control.

\section{Western blotting assay}

In order to collect proteins from cultured cells and tumors, the samples were washed with PBS and extracted using cell lysis buffer (GeneHunter, Basgvukke, TN, USA). After $20 \mathrm{~min}$ standing, the lysates were centrifuged at $12000 \times \mathrm{g}$ for $10 \mathrm{~min}$ at $4^{\circ} \mathrm{C}$. The protein concentration was measured by Bio-Rad protein assay (Bio-Rad, Hercules, CA, USA). Equal amounts of proteins were subjected to $10 \%$ SDS-PAGE gel for electrophoresis for $2 \mathrm{~h}$, then transferred to Millipore Immobilon-P Transfer Membrane (Millipore Corporation, Billerica, MA, USA) at $100 \mathrm{~mA}$ for $2 \mathrm{~h}$. Western blot analysis was performed with primary antibodies against ATG-5, LC3-I, LC3II, GAPDH, caspase-3, EphB4, and VEGFR-1, and incubated at $4{ }^{\circ} \mathrm{C}$ overnight. We washed the membranes and probed them with appropriate secondary antibodies for $2 \mathrm{~h}$ at room temperature. We measured protein levels using electrochemiluminescence (ECL) (Thermo Fisher Scientific, Rockford, IL, USA).

\section{Microarrays and gene expression analysis}

HepG2 cells were treated with $400 \mathrm{mM}$ AND, $6.23 \mu \mathrm{M} \mathrm{As}_{2} \mathrm{O}_{3}$, combination treatment, or vehicle $(0.1 \%$ DMSO) for $48 \mathrm{~h}$. After treatment, the cells were washed with PBS twice and suspended in $1.0 \mathrm{~mL}$ Trizol reagent (Life Technologies, Inc., Carlsbad, CA, USA). Then, microarray analysis was performed using Kangchen Bio-Tech (Shanghai, China) according to Agilent Whole Human genome Oligo microarray protocol. The microarray data were accessible via Gene Expression Omnibus.

\section{Quantitative real-time PCR analysis}

To validate the effect of combination treatment of andrographolide with $\mathrm{As}_{2} \mathrm{O}_{3}$ on the levels of EphB4 in vivo and in vitro, we performed qRT-PCR analysis. The mice were sacrificed and tumors were excised and minced into small pieces and then homogenized. In addition, HepG2 
Table 2: The primer sequences used for real-time polymerase chain reaction

\begin{tabular}{lll}
\hline \multicolumn{1}{c}{ Genes } & & \multicolumn{1}{c}{ Primes $\mathbf{( \mathbf { 5 } ^ { \prime } \mathbf { - 3 } \mathbf { 3 } ^ { \prime } )}$} \\
\hline EphB4 & sense: & CCTTCCTGCGGCTAAACGAC \\
& antisense: & GTTGACTAGGATGTTGCGAG \\
VEGFR1 & sense: & GAGAGTTCGGCTAGATCAAC \\
& antisense: & CGGATGTAGTTCGCCGAATG \\
Ras & sense: & TGACGCAGATCAAGTGTGAGA \\
& antisense: & ACTCCATGCACAGGTACGA \\
GAPDH & sense: & GGCATGGACTGTGGTCATGAG \\
& antisense: & TGCACCACCAACTGCTTAGC \\
\hline
\end{tabular}

cells were treated with the indicated treatments for $48 \mathrm{~h}$. Then, total RNA was isolated from tumor tissues and HepG2 cells using Trizol reagent (Life Technologies, Inc., Carlsbad, CA, USA) and treated with DNase I according to the manufacturer's instructions. We used Nano assay kit (Nanodrop Technologies, Wilmington, DE, USA) to test for RNA integrity. Amplification of cDNA was performed by real time PCR using the appropriate prime pairs: EphB4 or VEGFR-1. All primers were purchased from Sigma Aldrich (St. Louis, MO, USA) and are listed in Table 2. Quantitative PCR was performed using the CFX Connect Real-Time PCR Detection System (Bio-Rad Laboratories, Hercules, CA, USA).

\section{Animal experiments}

Thirty-two male BALB/c six-week-old nude mice were purchased from Vital River Laboratory Animal Technology Co., Ltd (Beijing, China). The mice were housed in a pathogen-free environment and all animals received human care according to Chinese legal requirements. HepG 2 cells $\left(3 \times 10^{6}\right.$ cells $)$ were injected subcutaneously into the dorsal flanks of mice. Tumor volumes were calculated as $\mathrm{V}\left(\mathrm{mm}^{3}\right)=0.5 \times \mathrm{L} \times \mathrm{W} \times \mathrm{H}$. When the tumor volume reached $200 \mathrm{~mm}^{3}$, the tumorbearing mice were randomly divided into four groups. The mice were administered intraperitoneal injections (i.p.) of vehicle control (0.1\% DMSO), andrographolide (20 mg/ $\mathrm{kg}), \mathrm{As}_{2} \mathrm{O}_{3}(5 \mathrm{mg} / \mathrm{kg})$, or the $\mathrm{As}_{2} \mathrm{O}_{3}$ with andrographolide ("combination treatment") for five weeks. The body weights and tumor volumes of xenografts were monitored weekly. At the end of the study, the mice were euthanized, and the tumors were harvested and weighed. All animal experiments were performed in accordance with protocols approved by The United Kingdom Coordinating Committee on Cancer Prevention Research's Guidelines for the Welfare of Animals in Experimental Neoplasia.

\section{TUNEL assay}

We performed TUNEL staining using a commercial kit (Roche Molecular Biochemicals, Indianapolis, IN) according to manufacturer's protocol to determine the mode of cell death in vivo. In brief, tissue sections were fixed with $1 \%$ paraformaldehyde for $15 \mathrm{~min}$ and incubated with a cold solution of ethanol:acetic acid $(2: 1)$ for an additional $5 \mathrm{~min}$. The sections were subsequently rinsed twice using PBS, immersed in $0.5 \%$ Triton for $15 \mathrm{~min}$ at $4^{\circ} \mathrm{C}$, then washed twice and digested with endogenous peroxidase with $3 \% \mathrm{H}_{2} \mathrm{O}_{2}$ for $20 \mathrm{~min}$. After washing twice with PBS, the slides were incubated with TdT enzyme at $37^{\circ} \mathrm{C}$ for $90 \mathrm{~min}$ and $3 \%$ hydrogen peroxide for $5 \mathrm{~min}$ to block endogenous peroxidase activity, and then treated with peroxidase conjugated antibody for $10 \mathrm{~min}$ at room temperature. Finally, the sections were examined by light microscopy.

\section{Immunohistochemical staining assay}

Immunohistochemical staining was performed as previously described [39] to confirm the expression of EphB4 in HepG2 in vivo. Briefly, the sections were deparaffinized in xylene and then rehydrated in graded ethanol series prior to antigen retrieval for $20 \mathrm{~min}$. Later on, the sections were washed with PBS and blocked with $5 \%$ bovine serum albumin (BSA) for $1 \mathrm{~h}$ at room temperature and then washed with PBS. Sections were then incubated overnight at $4{ }^{\circ} \mathrm{C}$ with primary antibody polyclonal rabbit anti-EphB4 (1:500). The cells were washed again with PBS buffer and then incubated with secondary antibody for $1 \mathrm{~h}$ at room temperature. The staining was developed for 5 min using DAB chromogen (Dako, Glostrup, Denmark) and then each section was visualized with a light microscope.

\section{Statistical analysis}

All statistical data are presented as mean \pm SD. Student's $t$-test was applied to determine the statistical significance between control and experimental data. ${ }^{*}$ and $* *$ represent $p<0.05$ and $p<0.01$, respectively, for the difference between the experimental data and the control or negative group.

\section{CONFLICTS OF INTEREST}

The authors report no conflicts of interest. 


\section{FUNDING}

This work was supported by grants from the National Natural Science Foundation of China (no. 81401494) and the Henan Province Medical Science and Technology Project (no. 201403059).

\section{REFERENCES}

1. Cunningham SC, Tsai S, Marques HP, Mira P, Cameron A, Barroso E, Philosophe B, Pawlik TM. Management of early hepatocellular carcinoma in patients with well-compensated cirrhosis. Ann Surg Oncol. 2009; 16:1820-1831.

2. Pisani P, Parkin DM, Bray F, Ferlay J. Estimates of the worldwide mortality from 25 cancers in 1990. Int J Cancer. 1999; 83:18-29.

3. Ferenci P, Fried M, Labrecque D, Bruix J, Sherman M, Omata M, Heathcote J, Piratsivuth T, Kew M, Otegbayo JA, Zheng SS, Sarin S, Hamid SS, et al. Hepatocellular carcinoma (HCC): a global perspective. J Clin Gastroenterol. 2010; 44:239-245.

4. Jiang E, Shangguan AJ, Chen S, Tang L, Zhao S, Yu Z. The progress and prospects of routine prophylactic antiviral treatment in hepatitis B-related hepatocellular carcinoma. Cancer Lett. 2016; 379:262-267.

5. Zhou J. Arsenic trioxide: an ancient drug revived. Chin Med J (Engl). 2012; 125:3556-3560.

6. Shen ZX, Chen GQ, Ni JH, Li XS, Xiong SM, Qiu QY, Zhu J, Tang W, Sun GL, Yang KQ, Chen Y, Zhou L, Fang ZW, et al. Use of arsenic trioxide (As2O3) in the treatment of acute promyelocytic leukemia (APL): II. Clinical efficacy and pharmacokinetics in relapsed patients. Blood. 1997; 89:3354-3360.

7. Berenson JR, Yeh HS. Arsenic compounds in the treatment of multiple myeloma: a new role for a historical remedy. Clin Lymphoma Myeloma. 2006; 7:192-198.

8. Xie L, Guo W, Tang X, Yang Y, Xu J. Effects of arsenic trioxide on minor progressive high-grade osteosarcoma of the extremities metastatic to the lung: results of 39 patients treated in a single institution. Case Reports in Oncology. 2016; 9:610-628

9. Chen Z, Zhang H, Yang L, Jiang H, Guo S, Li Y, Tao S. Construction of a metabolomics profile of arsenic trioxide effect in gastric carcinoma cell line SGC7901. Acta Biochim Biophys Sin (Shanghai). 2016; 48:474-481.

10. Podolsky L, Oh M, Subbarayan PR, Francheschi D, Livingstone A, Ardalan B. 5-Fluorouracil/Leucovorin and arsenic trioxide for patients with refractory/relapsed colorectal carcinoma: a clinical experience. Acta Oncol. 2011; 50:602-605.

11. Lin Z, Chang D, Shao Y, Hsu C, Hsu C, Yeh K, Yang C, Hong R, Cheng A. Prognostic factors of survival in 236 advanced hepatocellular carcinoma patients enrolled in prospective clinical trials of systemic therapy. J Clin Oncol. 2009; 27:e15632.

12. Liu B, Pan S, Dong X, Qiao H, Jiang H, Krissansen GW, Sun X. Opposing effects of arsenic trioxide on hepatocellular carcinomas in mice. Cancer Sci. 2006; 97:675-681.

13. Zhang C, Qiu X. Andrographolide radiosensitizes human ovarian cancer SKOV3 xenografts due to an enhanced apoptosis and autophagy. Tumor Biol. 2015; 36:8359-8365.

14. Gu LL, Zhang XY, Xing WM, Xu JD, Lu H. Andrographolideinduced apoptosis in human renal tubular epithelial cells: Roles of endoplasmic reticulum stress and inflammatory response. Environ Toxicol Pharmacol. 2016; 45:257-264.

15. Zhou B, Zhang D, Wu X. Biological activities and corresponding SARs of andrographolide and its derivatives. Mini Rev Med Chem. 2013; 13:298-309.

16. Li Y, Yan H, Zhang Z, Zhang G, Sun Y, Yu P, Wang Y, $\mathrm{Xu}$ L. Andrographolide derivative AL-1 improves insulin resistance through down-regulation of NF-kappaB signalling pathway. Br J Pharmacol. 2015; 172:3151-3158.

17. Yang PY, Hsieh PL, Wang TH, Yu CC, Lu MY, Liao YW, Lee TH, Peng CY. Andrographolide impedes cancer stemness and enhances radio-sensitivity in oral carcinomas via miR-218 activation. Oncotarget. 2017; 17:4196-4207. https://doi.org/10.18632/oncotarget.13755.

18. Kim J, Lee J, Lee YM, Pramanick S, Im S, Kim WJ. Andrographolide-loaded polymerized phenylboronic acid nanoconstruct for stimuli-responsive chemotherapy. J Control Release. 2016; 16:31082-31083.

19. Wang D, Wang Z, Tian B, Li X, Li S, Tian Y. Two hour exposure to sodium butyrate sensitizes bladder cancer to anti-cancer drugs. Int J Urol. 2008; 15:435-441.

20. Pan BS, Wang YK, Lai MS, Mu YF, Huang BM. Cordycepin induced MA-10 mouse Leydig tumor cell apoptosis by regulating p38 MAPKs and PI3K/AKT signaling pathways. Sci Rep. 2015; 5:13372.

21. Fischer U, Schulze-Osthoff K. Apoptosis-based therapies and drug targets. Cell Death Differ. 2005; 12:942-961.

22. El-Serag HB, Mason AC. Rising incidence of hepatocellular carcinoma in the United States. N Engl J Med. 1999; 340:745-750.

23. Zhou J, Zhang Y, Li J, Li X, Hou J, Zhao Y, Liu X, Han X, Hu L, Wang S, Zhao Y, Zhang Y, Fan S, et al. Single-agent arsenic trioxide in the treatment of children with newly diagnosed acute promyelocytic leukemia. Blood. 2010; 115:1697-1702.

24. Huntly BJ, Gilliland DG. Leukaemia stem cells and the evolution of cancer-stem-cell research. Nat Rev Cancer. 2005; 5:311-321.

25. Kang SH, Song JH, Kang HK, Kang JH, Kim SJ, Kang HW, Lee YK, Park DB. Arsenic trioxide-induced apoptosis is independent of stress-responsive signaling pathways but sensitive to inhibition of inducible nitric oxide synthase in HepG2 cells. Exp Mol Med. 2003; 35:83-90. 
26. Akao Y, Nakagawa Y, Akiyama K. Arsenic trioxide induces apoptosis in neuroblastoma cell lines through the activation of caspase 3 in vitro. FEBS Lett. 1999; 455:59-62.

27. Luo Q, Li Y, Lai Y, Zhang Z. The role of NF-kappaB in PARP-inhibitor-mediated sensitization and detoxification of arsenic trioxide in hepatocellular carcinoma cells. J Toxicol Sci. 2015; 40:349-363.

28. Luo Q, Li Y, Deng J, Zhang Z. PARP-1 inhibitor sensitizes arsenic trioxide in hepatocellular carcinoma cells via abrogation of $\mathrm{G} 2 / \mathrm{M}$ checkpoint and suppression of DNA damage repair. Chem Biol Interact. 2015; 226:12-22.

29. Zhang XY, Yang SM, Zhang HP, Yang Y, Sun SB, Chang JP, Tao XC, Yang TY, Liu C, Yang YM. Endoplasmic reticulum stress mediates the arsenic trioxide-induced apoptosis in human hepatocellular carcinoma cells. Int J Biochem Cell Biol. 2015; 68:158-165.

30. Tomuleasa C, Soritau O, Fischer-Fodor E, Pop T, Susman S, Mosteanu O, Petrushev B, Aldea M, Acalovschi M, Irimie A, Kacso G. Arsenic trioxide plus cisplatin/ interferon alpha-2b/doxorubicin/capecitabine combination chemotherapy for unresectable hepatocellular carcinoma. Hematol Oncol Stem Cell Ther. 2011; 4:60-66.

31. Tu Y, He S, Fu J, Li G, Xu R, Lu H, Deng J. Expression of EphrinB2 and EphB4 in glioma tissues correlated to the progression of glioma and the prognosis of glioblastoma patients. Clin Transl Oncol. 2012; 14:214-220.

32. Brantley-Sieders D, Schmidt S, Parker M, Chen J. Eph receptor tyrosine kinases in tumor and tumor microenvironment. Curr Pharm Des. 2004; 10:3431-3442.

33. Li JL, Sainson RC, Oon CE, Turley H, Leek R, Sheldon H, Bridges E, Shi W, Snell C, Bowden ET, Wu H, Chowdhury PS, Russell AJ, et al. DLL4-Notch signaling mediates tumor resistance to anti-VEGF therapy in vivo. Cancer Res. 2011; 71:6073-6083.

34. Zhu XL, Chen P, Guo H, Hou WJ, Shi Y, Zhang T, Li Q, Zhang N. Relationships among differentiation degree, contrast-enhanced ultrasound and the expression of Ephb4/Ephrinb2 in primary hepatocarcinoma. Hepatogastroenterology. 2012; 59:1164-1167.

35. Dopeso H, Mateo-Lozano S, Mazzolini R, Rodrigues P, Lagares-Tena L, Ceron J, Romero J, Esteves M, Landolfi S, Hernandez-Losa J, Castano J, Wilson AJ, Ramon y Cajal S, et al. The receptor tyrosine kinase EPHB4 has tumor suppressor activities in intestinal tumorigenesis. Cancer Res. 2009; 69:7430-7438.

36. Chou TC. Preclinical versus clinical drug combination studies. Leuk Lymphoma. 2008; 49:2059-2080.

37. Galluzzi L, Aaronson SA, Abrams J, Alnemri ES, Andrews DW, Baehrecke EH, Bazan NG, Blagosklonny MV, Blomgren K, Borner C, Bredesen DE, Brenner C, Castedo M, et al. Guidelines for the use and interpretation of assays for monitoring cell death in higher eukaryotes. Cell Death Differ. 2009; 16:1093-1107.

38. Djavaheri-Mergny M, Amelotti M, Mathieu J, Besancon F, Bauvy C, Souquere S, Pierron G, Codogno P. NF-kappaB activation represses tumor necrosis factor-alpha-induced autophagy. J Biol Chem. 2006; 281:30373-30382.

39. Kashyap MK, Marimuthu A, Kishore CJ, Peri S, Keerthikumar S, Prasad TS, Mahmood R, Rao S, Ranganathan P, Sanjeeviah RC, Vijayakumar M, Kumar KV, Montgomery EA, et al. Genomewide mRNA profiling of esophageal squamous cell carcinoma for identification of cancer biomarkers. Cancer Biol Ther. 2009; 8:36-46. 